\section{Introduction of the dengue virus type 4 in the State of Mato Grosso do Sul, Brazil}

\author{
Introdução do vírus dengue sorotipo 4 no Estado \\ de Mato Grosso do Sul, Brasil
}

\author{
Introducción del serotipo de virus dengue 4 en el \\ Estado de Mato Grosso do Sul, Brasil
}

A

Abstract

We report on the first isolation of dengue virus serotype 4 (DENV-4) in the State of Mato Grosso do Sul, Brazil, in February, 2012. The cases were isolated in the city of Campo Grande, the state capital, and presented the classic signs and symptoms of dengue fever. DENV-4 was primarily identified through viral isolation in C6/36 clone lineage of Aedes albopictus cells; followed by indirect immunofluorescence, using type-specific monoclonal antibodies. The results were subsequently confirmed by Nested RT-PCR tests. The first description of the introduction of DENV-4 in a state whose population is susceptible to this serotype and the circulation of three other serotypes in the area is cause for concern due to the increased possibility of severe and lethal cases of the disease, and of huge epidemics.

Dengue; Dengue Virus; Communicable Diseases
Lívia Garcia Bertolacci-Rocha 1 Rivaldo Venâncio da Cunha 1 Gislene Garcia de Castro Lichs 2 Márcia Maria Ferrairo Janini Dal Fabbro 1 Ana Rita Coimbra Motta-Castro 1

\section{Resumo}

Relatamos o primeiro isolamento do vírus dengue sorotipo 4 (DENV-4) no Estado de Mato Grosso do Sul, Brasil, em fevereiro de 2012. Os casos foram isolados na cidade de Campo Grande, capital do estado, e apresentaram sinais e sintomas clássicos da febre do dengue. O DENV-4 foi primeiramente identificado por isolamento viral em clone C6/36 linhagem de células de Aedes albopictus seguido por imunofluorescência indireta, utilizando anticorpos monoclonais tipoespecíficos. Os resutlados foram posteriormente confirmados por testes de Nested RT-PCR. A descrição de sua introdução pela primeira vez neste estado, com população suscetivel a este sorotipo e onde já circularam os outros três sorotipos é muito preocupante, pois aumenta a possibilidade de ocorrer formas graves e letais desta doença, assim como possibilita a ocorrência de grandes epidemias.

Dengue; Vírus da Dengue; Doenças

Transmissiveis 
Dengue viruses are the etiological agents responsible for the human viral disease that has the greatest impact on humans, in terms of morbidity and mortality, among diseases transmitted by mosquitoes. This illness is a serious public health problem in tropical and subtropical countries. Dengue viruses are considered reemerging viruses due to an increase in their incidence and prevalence and an expansion of their geographic range over the last decades; and also due to an aggravation of clinical cases, that may lead to death 1 . These viruses present four serotypes, which are serologically related and antigenically distinct, described as DENV-1, DENV-2, DENV-3 e DENV-4 2 .

In Brazil, dengue is considered an endemic disease, associated with epidemic outbreaks. In 1981, Osanai et al. ${ }^{3}$ presented the first case report with laboratory etiologic evidence in Brazil, in the State of Roraima in the North of the country, showing the serotypes DENV-1 and DENV-4. In 1981, the disease had not been established despite the presence of autochthonous cases. Only after an epidemiological silence in 1986/1987 was the first dengue epidemic reported with DENV-1 found to be the only virus proven to be circulating in several states in the Southeast and Northeast of the country 4,5 .

The reemergence of DENV-4 in Brazil occurred in 2010 in BoaVista, the capital of the state of Roraima, which was also the same place where the viruses were identified in 1981. This serotype had not been detected in Brazil for almost 30 years 6 . DENV-4 later reached other states in the North (Amazon and Pará), the Northeast (Piauí, Pernambuco, Bahia and Ceará), the Southeast (Rio de Janeiro and São Paulo) and the South (Rio Grande do Sul) giving rise to epidemics (Brazilian Institute for Geography and Statistics. http:/ / www.censo2010.ibge.gov.br, acessed on 27/ Mar/2012) 7,8,9.

Mato Grosso do Sul is considered an endemic area for dengue viruses. It was noted that, over the years, the introduction of a new serotype in the state caused the emergence of new epidemics 10 . It is important to note the geographic importance of the state, because it is bordered by two countries (Paraguay and Bolivia) and five heavily populated Brazilian states (Mato Grosso, Goiás, Minas Gerais, São Paulo and Paraná). Furthermore, Aedes aegypti are usually found in high densities and are considered excellent vectors of dengue viruses 11 .

The introduction of a new serotype (DENV-4) in Mato Grosso do Sul is being observed with extreme concern. This is because the serotype has the potential to give rise to epidemics in the region, because of the high vector density and population susceptibility to this serotype. In 2012 there was co-circulation of DENV-1 and DENV-2, and with the introduction of DENV-4 for the first time in the state, there could be an increase in deaths and in more severe forms of the disease.

The aim of this study was to report the introduction of DENV-4 for the first time in Mato Grosso do Sul. Virus isolation and a reverse transcription polymerase chain reaction (RTPCR) were performed. The virus was isolated in all cases by cell culture inoculation in the C6/36 Aedes albopictus cell line 12. The viral identification of serotypes was confirmed by indirect immunofluorescence using monoclonal antibodies. In addition, all cases were confirmed by RTPCR 13 in serum samples.

The first cases of DENV-4 detected in Mato Grosso do Sul were in Campo Grande (20²6'34”'S, $54^{\circ} 38^{\prime} 47^{\prime \prime} \mathrm{W}$ ), which is the state capital, and the most populous city in the state, with 787,204 inhabitants. After the introduction of DENV-4 in Mato Grosso do Sul, a large dengue epidemic occurred in the summer of $2012 / 2013$, with 43,464 notifications reported in the first seven weeks. During this period, 15 of these cases resulted in mortalities 14 .

Almost a year after the introduction of DENV-4, this serotype was found to be the main one circulating. It was responsible for the most serious dengue outbreak in the history of the state in terms of the number of cases reported, the severity of clinical manifestations, and the number of confirmed deaths.

In this study, we report the first isolation of DENV-4 in February 2012 in the State of Mato Grosso do Sul, from three patients in the city of Campo Grande. The onset of symptoms in a male occurred on 12 February 2012 (MSH 102 001738); in a female on 21 February 2012 (MSM 102-002058); and in another female on 29 February 2012 (MSM 102-002500). The main symptoms of the patients were fever, headache and myalgia, compatible with suspicion of dengue. The disease progress was satisfactory, with complete recovery for these patients (Table 1).

Since the 1990s, Mato Grosso do Sul state has seen an intense growth of its population and an increase in the construction of buildings. The region has reported a significant number of dengue cases over the last ten years and always contributes to viral circulation research by providing samples. Although there was co-circulation of serotypes DENV-1 and DENV-2 during the first trimester of 2012, an effective surveillance system allowed for the early detection of the first cases of DENV-4.

The introduction of DENV-4 in this region is worrying, and makes it essential to ensure the 
Signs, symptoms and laboratory findings of the first cases of DENV-4 in 2012, Campo Grande, Mato Grosso do Sul State, Brazil.

\begin{tabular}{|c|c|c|c|c|c|c|c|c|c|}
\hline \multicolumn{10}{|c|}{ Patient } \\
\hline & 1 & 2 & 3 & 4 & 5 & 6 & 7 & 8 & 9 \\
\hline Age/Sex & 35/Female & 70/Female & 51/Male & 19/Female & 17/Female & 65/Male & 37/Female & 37/Male & 24/Male \\
\hline Fever & + & + & + & + & - & + & + & + & + \\
\hline Headache & + & + & + & + & + & + & + & + & + \\
\hline Retro-orbital pain & + & - & + & - & + & + & + & + & + \\
\hline Myalgia & + & + & + & + & + & + & + & + & + \\
\hline Arthralgia & + & - & + & + & + & + & + & - & - \\
\hline Tourniquet & - & + & + & + & - & - & - & - & - \\
\hline Platelets & 132 & 143 & 150 & 141 & 190 & $\mathrm{NI}$ & 119 & 117 & 101 \\
\hline Hemoglobin & 11.5 & 13.4 & 15.4 & 9.2 & 11.9 & $\mathrm{NI}$ & 12.7 & 13.3 & 15.0 \\
\hline Hematocrit & 36 & 40 & 46 & 31 & 40 & $\mathrm{NI}$ & 38 & 43 & 48 \\
\hline $\begin{array}{l}\text { Serum alanine } \\
\text { aminotrasferase }\end{array}$ & 60 & 49 & 45 & $\mathrm{NI}$ & 28 & 49 & 34 & 87 & $\mathrm{NI}$ \\
\hline $\begin{array}{l}\text { Serum aspartate } \\
\text { aminotransferase }\end{array}$ & 47 & 54 & 33 & $\mathrm{NI}$ & 9 & 32 & 22 & 47 & $\mathrm{NI}$ \\
\hline IgM anti-DENV & + & - & + & - & + & + & - & + & + \\
\hline $\begin{array}{l}\text { Viral isolation to } \\
\text { DENV-4 }\end{array}$ & + & + & + & + & + & + & + & + & + \\
\hline RT-PCR to DENV-4 & + & + & + & + & + & + & + & + & + \\
\hline
\end{tabular}

NI: not informed.

use of rapid and sensitive laboratory diagnostic techniques to guarantee early detection of the cases. There is an increased possibility of severe forms of the disease occurring due to the high number of susceptible people, the high vector density and the occurrence of several epidemics with the circulation of other serotypes. Serological and virological investigations should be encouraged to avoid or minimize the spread of this new serotype, and thereby prevent the occurrence of a new outbreak.

The introduction of this new serotype, resulted in a major epidemic that represents a new threat, since DENV-4 has been associated with atypical forms of the disease, especially during
2012, when the introduction of a new serotype and co-circulation of serotypes DENV-1 and DENV-2 was reported.

The introduction of DENV-4 in 2012, associated to its presence in bordering countries, combined with high levels of infestation by the vector $A$. aegypti, and also a susceptible population, resulted in the occurrence of the largest epidemic recorded in Mato Grosso do Sul. Additionally, the absence of a vaccine to prevent infection by DENV on a large scale means that virologic surveillance serves as an important tool for preventing outbreaks and epidemics, and that the laboratory has a fundamental role to play in monitoring these infections. 


\section{Resumen}

Informe del primer aislamiento del serotipo del virus dengue 4 (DENV-4) en el Estado de Mato Grosso do Sul, Brasil, en febrero de 2012. Los casos fueron aislados en la ciudad de Campo Grande, capital del estado, y que presentan signos y síntomas de fiebre de dengue clásico. El DENV-4 se identificó principalmente a través de aislamiento viral en C6/36 con linaje de células de Aedes albopictus; seguido por inmunofluorescencia indirecta, utilizando anticuerpos monoclonales específicos de tipo. Después, fueron confirmados por pruebas de RT-PCR anidada. La descripción de la introducción del DENV-4 por primera vez en este estado, asociado a una población susceptible a este serotipo, y también la circulación de los otros tres serotipos en la zona es muy preocupante. La razón de esta preocupación es la mayor posibilidad de que se produzcan casos severos y letales de la enfermedad, así como, la aparición de grandes epidemias.

Dengue; Virus del Dengue; Enfermedades Trasmisibles

\section{Contributors}

L. G. Bertolacci-Rocha, R. V. Cunha, G. G. C. Lichs, M. M. F. J. Dal Fabbro and A. R. C. Motta-Castro are responsible for all aspects of the work: conception and design of the study, gathering, analysis and interpretation of data, drafting and revising the article, and final approval of the version to be published.

\section{Acknowledgments}

To LACEN and Nathália Fontoura for tecnhical support.

\section{References}

1. Azevedo RSS, Martins LC, Rodrigues SG, Travassos-da-Rosa JFS, Vasconcelos PFC. Arboviroses. In: Farhat CK, Carvalho LHFR, Succi RCM, organizadores. Infectologia pediátrica. 3a Ed. São Paulo: Editora Atheneu; 2007. p. 533-51.

2. Westaway EG, Brinton MA, Gaidamovich SY, Horzinek MC, Igarashi A, Kaariainen L, et al. Flaviviridae. Intervirology 1985; 24:183-92.

3. Osanai CH, Rosa AP, Tang AT, Amaral RS, Passos AD, Tauil PL. Surto de dengue em Boa Vista, Roraima. Rev Inst Med Trop São Paulo 1983; 25:53-4.

4. Nogueira RMR, Miagostovich MP, Schatzmayr HG, Santos FB, Araujo ES, Filippis AMB, et al. Dengue in the state of Rio de Janeiro, Brazil 1986-1998. Mem Inst Oswaldo Cruz 1999; 93:297-304.

5. Teixeira MG, Barreto ML, Guerra Z. Epidemiologia e medidas de prevenção do dengue. Inf Epidemiol SUS 1999; 8:5-33.

6. Temporão JG, Penna GO, Carmo EH, Coelho GE, Azevedo RSS, Nunes MRT, et al. Dengue virus serotype 4, Roraima State, Brazil. Emerg Infect Dis 2011; 17:938-40.

7. Coordenação Geral do Programa Nacional de Controle da Dengue, Secretaria de Vigilância em Saúde, Ministério da Saúde. Balanço dengue. Brasília: Ministério da Saúde; 2011.

8. Nogueira RMR, Eppinghaus ALF. Dengue virus type 4 arrives in the state of Rio de Janeiro: a challenge for epidemiological surveillance and control. Mem Inst Oswaldo Cruz 2011; 106: 255-6.

9. Rocco IM, Silveira VR, Maeda AY, Silva SJS, Spenassatto C, Bisordi I, et al. First isolation of dengue 4 in the state of São Paulo, Brazil. Rev Inst Med Trop São Paulo 2011; 54:49-51.

10. Cunha RV, Marques Filho VS, Aguiar JIA, Paniago AMM, Lindenberg ASC, Hans Filho G, et al. Dengue hemorrágico em Campo Grande, MS: relato do primeiro caso diagnosticado. Rev Soc Bras Med Trop 1996; 29 Suppl 1:57.

11. Teixeira MG, Costa MCN, Barreto ML, Mota E. Dengue and dengue hemorrhagic fever epidemics in Brazil: what research is needed based on trends, surveillance, and control experiences? Cad Saúde Pública 2005; 21:1307-15.

12. Gubler DJ, Kuno G, Sather GE, Velez M, Oliver A Mosquito cell culture and specific monoclonal antibodies in surveillance for dengue viruses. Am J Trop Med Hyg 1984; 33:158-65.

13. Lanciotti RS, Calicher CH, Gubler DJ, Chang GJ, Vorndam V. Rapid detection and typing of dengue viruses from clinical samples by using reverse transcriptase-polymerase chain reaction. J Clin Microbiol 1992; 30:545-51.

14. Secretaria de Estado de Saúde de Mato Grosso do Sul. Boletim epidemiológico no 6 - Dengue - semana 1 a 7 . http://www.saude.ms.gov.br/index. php?templat $=$ vis \&site $=116 \& i d \_c o m p=544 \&$ id reg $=197371 \&$ voltar=home\&site_reg $=116 \&$ id comp_orig=544 (accessed on 05/May/2014).

Submitted on 12/Jan/2014

Final version resubmitted on 13/May/2014

Approved on 19/May/2014 